\title{
MINANGKABAU CULTURE AND ITS IMPLEMENTATION AT PADANG RESTAURANT MANAGEMENT IN YOGYAKARTA INDONESIA
}

\author{
Henny Welsa \\ Magister Management of Sarjana Taman Wiyata \\ University, Yogyakarta, Indonesia \\ henny_welsa@yahoo.com
}

\author{
Lathifah \\ Magister Management of Sarjana Taman Wiyata \\ University, Yogyakarta, Indonesia \\ lalakuspri@yahoo.com
}

\begin{abstract}
The research was intended to identify the cultural factors that influenced entrepreneurship, business skills, and performance of Padang restaurant business in Yogyakarta Special Region. It is expected that the research will directly encourage entrepreneurship in Indonesia and provide a solution to the employment and unemployment rates in Indonesia and particularly in Yogyakarta. The research objects were Padang restaurants who already have a business license. The reason for choosing Yogyakarta as the setting was because Yogyakarta represents a student city and a tourist destination. Its population consists of diverse ethnic groups and $60 \%$ of the regional revenue comes from tourism where one of the tourism facilities is restaurant. Padang Restaurant has been developing rapidly in Yogyakarta area. The number of respondents were 50 Padang restaurant owners. The research instrument was a questionnaire and the data were analyzed by employing anayized deskriptive. The research result shows that Minangkabau culture and Yogyakarta culture significantly affects the entrepreneurship, business capabilities, and business performance; whereas entrepreneurship does not significantly affect the capability of business to performance.
\end{abstract}

Keywords: Minangkabau culture, Yogyakarta culture, entrepreneurship, business competence, business performance

\section{INTRODUCTION}

Basically the purpose of this research is to studying the effect of cultural factors towards entrepreneurship, business abilities and performance Padang Restaurant Business in Yogyakarta Special Region. This is expected to directly encourage entrepreneurship in Indonesia and be a solution to the absorption of labor and unemployment in Indonesia and in particular in DIY. The reason why this research discusses about Padang restaurant business is to assist the government in overcoming unemployment. Padang restaurant performance can be known by testing and analyzing the factors that affect the Padang Restaurant. The expectation of this research is founding the changing steps for a better condition.

Yogyakarta Special Region was selected as research area because Yogyakarta is a city of students and tourism whose population consist of diverse tribes. Yogyakarta Local Revenue 60\% comes from Tourism where one of tourism facilities is Restaurant. The growth of Padang Restaurant is quite fast in Yogyakarta Special Region. [20] in his research explains that entrepreneur is an asset or development capital that must be maintained and expanded in society, especially educated society. So that in turn able to support the acceleration of development of the country, on the one hand and reduce the burden of the state on the other.

Entrepreneur is an activity of human resource development which is motivated by socio-cultural condition as found in Minangkabau society, especially in Padang Restaurant business. Geographical and sociological conditions are sustained by Minangkabau culture, among others, to foster the values and behavior of wanderers as the characteristics and behavior of migration and in the economic aspect bring up entrepreneurship that grows in the institution of Padang Restaurant. Cultural studies provide a signal that the existence of the institution was supported by the strength of Minangkabau cultural values that successfully provide a foundation value for the growth of work ethic in the management of the restaurant.

Based on the description above, it can be concluded that if compared with some previous research, this research: using 5 (five) indicator of Minangkabau culture which in dissertation from [27] revealed that only use 3 indicator to measure cultural variable and eight indicator of soul Entrepreneurship to measure entrepreneurial variables, ten indicators of business ability to measure business ability variable and four business performance indicators to measure business performance variables Padang Restaurant.

The purpose of this research is to find out whether Yogyakarta culture influences the entrepreneurial spirit of Minangkabau society and its influence also on entrepreneurship, especially at business ability and business performance of Padang Restaurant in Yogyakarta.

\section{METHODS}

As has been shown in the roadmap or research flow that this research consists of several stages. Stages of the research can be briefly seen in the table below (Table 1). Here is an elaboration of operational definitions, indicators:

\section{Definitions \& Indicators}

Minangkabau culture is a life concept prepared by the ancestors of the Minang people for their offspring, which aims to achieve a happy and prosperous world life and the hereafter. Minangkabau culture is measured based on indicators developed by [6] states that cultural indicators of minangkabau consist of education and religion as well as family values. Meanwhile, according to [27] cultural indicators of minangkabau consist of religion, education in the family, and wander.

Entrepreneurship is a grouping of variables that describe the traits or characteristics of an individual that is reflected in the management and development of his own company while creating jobs for others. In the 
study [27] explains that entrepreneurship is measured by eight indicators: (1) vision, (2) planning, (3) motivation, (4) innovation, (5) opportunities, (6) confidence, (7) risk, and (8) adaptation. Business Ability in determining the policy of production, marketing and finance from before going to production process until after goods used or used by consumer.

Business capacity indicators are: (1) raw materials, (2) labor, (3) technology, (4) product quality
(5) price, (6) product variation, (7) market range, (8) ease of buying, and (9) availability of capital [5]. The business performance which is the identification of business success from Padang restaurant in DIY is measured by three indicators, namely: (1) number of labor, (2) productivity, and (3) sales growth. This is consistent with [27] study.

Table 1

Research Consists of Several Stages

\begin{tabular}{|c|c|c|}
\hline Research & $\begin{array}{l}\text { - The impact of Yogyakarta c } \\
\text { capability; and business per }\end{array}$ & $\begin{array}{l}\text { ulture on Minang culture in its implications on, business } \\
\text { ormance }\end{array}$ \\
\hline Research Variables & $\begin{array}{ll}\text { - } & \text { Dependent variables } \\
\text { - Independent variables } \\
\text { - }\end{array}$ & $\begin{array}{l}\text { : business ability (Y1) and business performances (Y2) } \\
\text { : Minangkabau Culture }(\mathrm{X} 1)] \\
\text { : Yogyakarta Culture }(\mathrm{X} 2)\end{array}$ \\
\hline Methods of research & $\begin{array}{ll}\text { - } & \text { Methods of data collection } \\
\text { - } & \text { Population } \\
\text { - } & \text { Samples } \\
\text { - } & \text { Sample Method } \\
\text { - } & \text { Test instrument } \\
\text { - } & \text { Data analysis }\end{array}$ & $\begin{array}{l}\text { : questionnaire } \\
: \text { Padang Restaurant in Yogyakarta Special Region } \\
\text { : } 50 \text { Padang Restaurant in Yogyakarta Special Region } \\
\text { : proportional stratified random sampling, } \\
\text { : test validity and reliability } \\
\text { : descriptiveAnalysis }\end{array}$ \\
\hline Place of study & \multicolumn{2}{|c|}{ - Special Region of Yogyakarta } \\
\hline
\end{tabular}

\section{RESULTS AND DISCUSSION}

\section{Padang Restaurant}

Padang Restaurant which is used as the main object in this research is a private business institution engaged in selling services and food products typical of Minangkabau region. The name of Rumah Makan Padang is still used in medium-sized and medium-sized restaurants, whose origin is lapis. Padang restaurant has its own characteristics in the arrangement of the room, although adapted to the condition of the room, but has the same pattern. Room arranged into three parts that have special functions.

Consists of the back as a production center, the center as a market center and on the front of the room there is a cashier there as well as a Trench where peddle dishes ready to serve. Trench in large restaurants are usually placed in the middle somewhat laterally facing rows of chairs and tables of guests. For middle and small restaurant the trench is in front with the cashier. This situation is one of the characteristics in the spatial arrangement of Padang Restaurant.

\section{Description of Research Variables}

This research used descriptive analysis with the help of statistical program SPSS ver. 13 to describe the research variable:

Table 2

Description Analysis of Minangkabau Cultural Variables

\begin{tabular}{|c|c|c|c|}
\hline No. & Indicator & Score & Average \\
\hline $\mathbf{A}$ & Religious Indicator & & \\
\hline 1 & The type of food suitable is kosher & 231 & 4.62 \\
\hline 2 & Considering employee recruitment still sees the religious factor adopted & 196 & 3.9 \\
\hline 3 & The restaurant is held inter-worker recitation & 194 & 3.9 \\
\hline 4 & Each year the restaurant issuing Zakat to employees & 192 & 3.8 \\
\hline 5 & Every year the restaurant issuing Qurban for employees & 153 & 3.1 \\
\hline \multirow[t]{2}{*}{6} & Restaurant owners conduct recitation using profit sharing & 163 & 3.3 \\
\hline & TOTAL & 1129 & 22.62 \\
\hline $\mathbf{B}$ & Foreign Indicator & & \\
\hline 1 & Restaurant owner go to Yogyakarta to start business & 193 & 3.9 \\
\hline 2 & The restaurants owners go to other city to make money for better economic life & 209 & 4.2 \\
\hline 3 & Restaurant owners bring families from their homes to help run the restaurant & 153 & 3.1 \\
\hline \multirow[t]{2}{*}{4} & Overseas successful restaurant owner help to build the homeland & 163 & 3.26 \\
\hline & TOTAL & 718 & 14.46 \\
\hline $\mathbf{C}$ & Incicator of Education in the family & & \\
\hline \multirow[t]{2}{*}{1} & Restaurant owners get entrepreneurial education from their family & 189 & 3.8 \\
\hline & TOTAL & 189 & 3.8 \\
\hline D & Incicator Jobs & & \\
\hline 1 & Making sure that job as an entrepreneur is the main goal & 207 & 4.1 \\
\hline \multirow[t]{2}{*}{2} & Making sure that as an entrepreneur can guarantee the future & 195 & 3.9 \\
\hline & TOTAL & 402 & 8 \\
\hline $\mathbf{E}$ & Indikator Community & & \\
\hline 1 & Had Confidential that entrepreneur is able to help overcome unemployment & 209 & 4.2 \\
\hline \multirow[t]{2}{*}{2} & Entrepreneurship is a prid & 197 & 3.9 \\
\hline & TOTAL & 406 & 8.1 \\
\hline
\end{tabular}




\section{Religion}

The indicator of religion issue is on the problem. The type of food is halal food is guaranteed halal 4.62 this is in accordance with Minangkabau Cultural philosophy based Minangkabau Culture philosophy. That is Indigenous encrypted Syarak, Syarak bersandikan Kitabullah is based on the rules of religion Islam. So the muslim people who is traveling abroad will always look for the restaurant because it is sure to believe his halal even without a halal certificate from MUI.

\section{Wander}

The owners of Padang Restaurant went abroad for a better family economic life as seen from the percentage of respondents who gave the answer strongly agreed the purpose of migrating to Yogyakarta is to live better than stay in the village with the average value of 4.2. From this data shows the culture wander its purpose to build the hometown has begun to shift.

\section{Entrepreneurial education in the family}

Entrepreneurship education is available in the family, as seen from the percentage of respondents who gave very useful answers. Entrepreneurship education in the family with the number of 50 respondents or $100 \%$.
In free interviews with some experienced respondents in their family, because they are used to living and thinking with a tenacious pattern, save saving or painstaking, patiently waiting for a better opportunity, never ever Despair and make failure as a lesson in fostering experience. This is in accordance with the results of research [12] which states specifically citizenship.

\section{Work}

Respondents' answer to the highest employment indicator is to say entrepreneurship is their primary goal so they no need to be an employee. The Research of [24] stated that the socio-demographic factors are the work of parents as entrepreneurs and students, entrepreneurship experience, attitudes including autonomy/authority, economic challenge, self realization, security \& workload, and contextual factors ie academic support and social support proved to have a significant and positive impact on entrepreneurial intentions.

\section{Society}

Respondents believe that being an entrepreneur can help the government in alleviating poverty and this is seen from the average score of 4.2 .

Table 3

Description Analysis of Yogyakarta Culture Variables

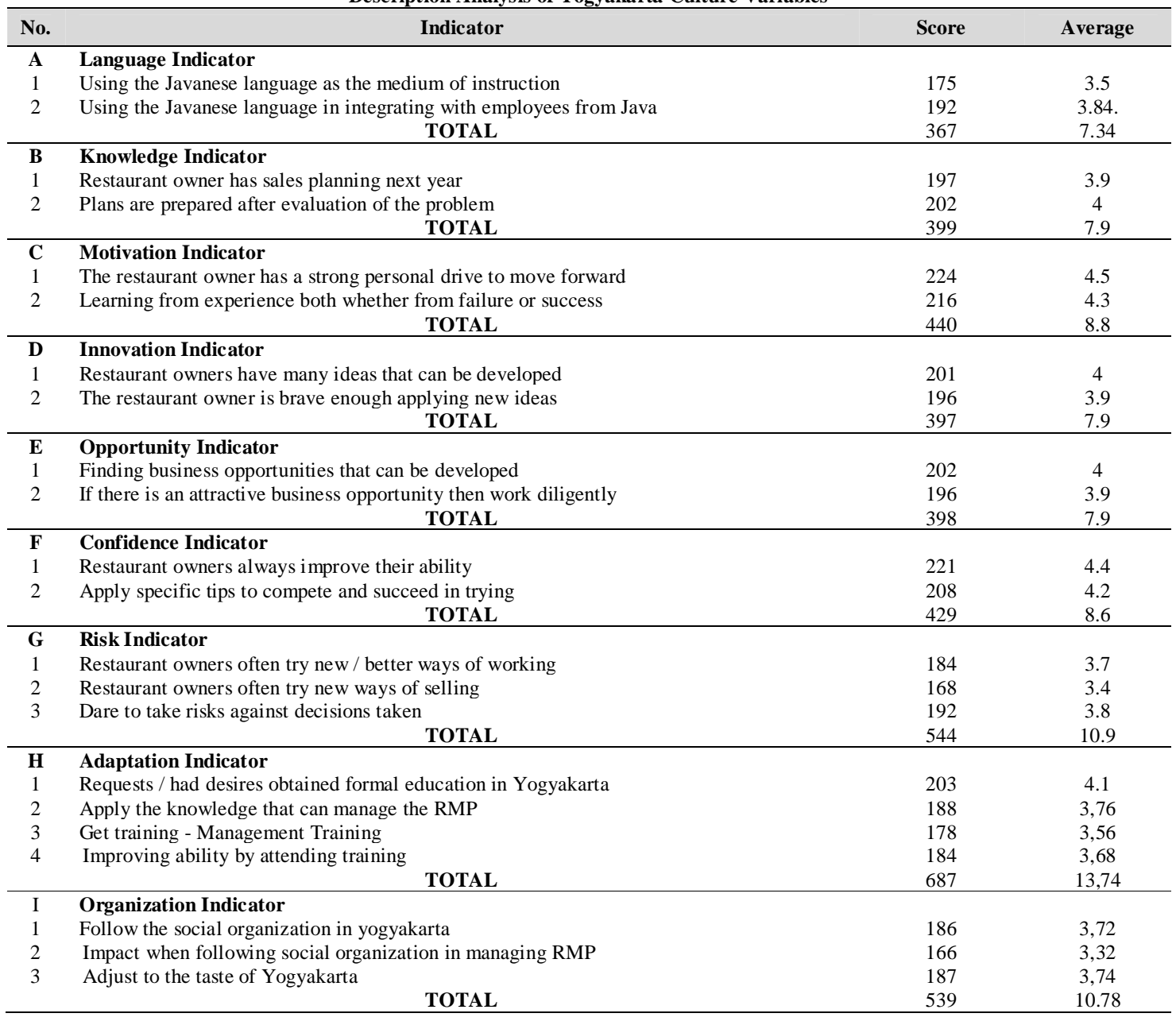




\section{Language}

Restaurant owners use the Javanese language as the medium of instruction in daily life from a high average value of 3.5 . The results show that the Javanese language has been used as a language of instruction daily life in addition to their mother tongue, the language Minang, especially when communicating with their children who were born in Yogyakarta as well as when interacting with employees who are from Java and this is seen from the average which is 3.84 high.

\section{Knowledge}

Restaurant owners generally get education in Yogyakarta. From the descriptive results it is seen that the restaurant owners apply the knowledge gained in managing the restaurant and always improve the ability to follow the training and this can be seen from the descriptive results of the average-3.76.
Every business owners have different requests or buyer desires that always served according to their wishes it is seen from the highest average value of 3.74. The owner maintain an old family heritage prescription and make adjustments. From the results of interviews can be concluded that the respondents are easy to adapt to the environment but the identity will never disappear, as the following saying: dima bumi dipijak, di sinan langik dijunjung di ma nagari diunyi, disinan adat dipakai (where the earth is rested, there the sky is upheld where the land is inhabited, there is customary use) [6].

The saying goes that minang culture values can be implemented anywhere, as long as good at adjusting to the society being pursued. Telling people to be able to adjust to the community where he is and it is done with the respondent always follow the social organization environment.

\section{Organization}

Table 4

Description Analysis of Business Capability Variables

\begin{tabular}{|c|c|c|c|}
\hline No. & Indicator & Score & Average \\
\hline $\mathbf{A}$ & Raw Material Indicator & & \\
\hline 1 & Restaurant owners easily obtain the raw materials that needed during production & 201 & 4 \\
\hline 2 & Restaurant owners are easy to supply raw materials on time when needed & 202 & 4 \\
\hline \multirow[t]{2}{*}{3} & Owners had a good relationships with suppliers so its easy to obtain raw materials & 203 & 4.1 \\
\hline & TOTAL & 606 & 12.1 \\
\hline $\mathbf{B}$ & Labor Indicator & & \\
\hline 1 & The owner of the restaurant is easy to obtain labor & 162 & 3.2 \\
\hline 2 & Restaurant owners encourage employees to continue improving their skills & 194 & 3.9 \\
\hline \multirow[t]{2}{*}{3} & Wage system and working atmosphere are made to encourage employees to work as well as possible & 190 & 3.8 \\
\hline & TOTAL & 546 & 10.9 \\
\hline $\mathbf{C}$ & Production Technology Indicator & & \\
\hline 1 & Technological developments affect my business development & 182 & 3.6 \\
\hline \multirow[t]{2}{*}{2} & The equipment in the business used the latest one & 172 & 3.4 \\
\hline & TOTAL & 354 & 7 \\
\hline D & Product Quality Indicator & & \\
\hline 1 & The Products has produced in accordance with the wishes of consumers and have a good competitiveness & 201 & 4 \\
\hline \multirow[t]{2}{*}{2} & Restaurant owners follow environmental changes such as market tastes & 189 & 3.8 \\
\hline & TOTAL & 390 & 7.8 \\
\hline $\mathbf{E}$ & Indikator Harga & & \\
\hline 1 & The price is quite reasonable compared to other padang restaurants & 196 & 3.9 \\
\hline \multirow[t]{2}{*}{2} & Evaluate alternative prices & 178 & 3.6 \\
\hline & TOTAL & 374 & 7.5 \\
\hline $\mathbf{F}$ & Product Variation Indicator & & \\
\hline 1 & Restaurant owners often offer a new type of prod & 154 & 3.1 \\
\hline \multirow[t]{2}{*}{2} & Especial types and taste so that no one can imitate & 185 & 3.7 \\
\hline & TOTAL & 339 & 6.8 \\
\hline $\mathbf{G}$ & Market Range Indicator & & \\
\hline 1 & The main buyers of the products is students & 162 & 3.2 \\
\hline \multirow[t]{2}{*}{2} & Market coverage is around the surrounding area & 185 & 3.7 \\
\hline & TOTAL & 347 & 6.9 \\
\hline $\mathbf{H}$ & Buy Easy Indicator & & \\
\hline 1 & Delivery Order Availability & 189 & 3.4 \\
\hline \multirow[t]{2}{*}{2} & Accesible Location & 206 & 4.1 \\
\hline & TOTAL & 395 & 7.5 \\
\hline $\mathbf{I}$ & Capital Availability Indicator & & \\
\hline 1 & Financial factor is the main obstacle to developing the business & 188 & 3.8 \\
\hline 2 & Capital assistance has been obtained from banks & 152 & 3 \\
\hline & - & 340 & 6.8 \\
\hline
\end{tabular}

\section{Ability to Provide Raw Materials}

The owner are able to obtain the raw materials needed in production, they also have a good relationship with the supplier so that no difficulty in getting the raw material as it is seen from the same average value on all questions on raw materials that is 4. 
Labor

From the respondent's answer shows that the owner of the Restaurant is quite easy in obtaining employees and always encourage employees to continue to improve their skills and work with the atmosphere of kinship so that employees can work as well as possible as it seen the highest average grade of fault 3.9 .

\section{Forms of Production Technology Used}

Technological developments affect the development of business it is seen from the average value of 3.6. From the respondent's answer shows that the owner of Restaurant Padang has followed the development of technology as a means of production and technology is enough to influence the development of technology to facilitate the production process.

\section{Product quality}

Products produced in accordance with the wishes of consumers and have a good competitiveness it is seen from the highest average value of 4 . From the respondent's answer shows that the owner of the Restaurant Padang always maintain the quality of the product and always adjust to the tastes of consumers such as food taste is not too Spicy and salty.

\section{Price}

Price is quite competitive compared to other padang restaurant it is the highest value is 3.9. From the respondent's answer shows that the price is relatively competitive because the main target market of this business is the students and students financially limited so it is enough to affect the business continuity. Price changes will be evaluated in case of rising prices of raw materials.

\section{Product Variations}

Especial types and taste of dishes so that no one can imitate it looks as the highest value of 3.7. From the respondent's answer shows that the owner of Rumah Makan Padang always offer new types of food with a distinctive taste in order to compete with other Padang Restaurant.

\section{Market Reach}

The main buyers of the products are students as it looks the highest value of 3.7. The market reaches the area around the restaurant. From the respondent's answer indicates that the Padang Restaurant customers is students, especially students from Sumatra who live around the restaurant. Therefore usually Padang Restaurant always takes location approaching campus.

\section{Ease of Buying}

The location is easily affordable it looks the average highest value that is equal to 4.1. From the respondents' answers indicate that they agree the service innovation is inter service although not well done only for student around the location of restaurants or office employees who have become loyal customer of the Restaurant. The owners are looking for a location that is easily reachable by the market, because the potential market is students so the most of the restaurant owners are always looking for location around the campus.

\section{Capital Availability}

The financial factor / cost is the main obstacle to develop the business it looks from highest average that is equal to 3.8 From the respondent's answer indicates that the owner of Restaurant Padang replied that the capital is a major obstacle in developing their business and one alternative to solve it is by borrowing capital through services banking.

\section{Total Manpower}

The number of workers is in accordance with the needs, abilities and expertise of each it looks the same average value of 4 .

\section{Labor Productivity}

In general, respondents were satisfied with the performance of employees it looks average value of 3.8 .

\section{Sales Growth}

The sales growth of the last three years is relatively increasing as seen from the average value of 3.8.

Table 5

Decription Analysis of Business Performance Variables

\begin{tabular}{clrr}
\hline No. & \multicolumn{1}{c}{ Indicator } & Score & Average \\
\hline A & Number of Relative Workers Indicator & 207 & \\
\hline 1 & The number of workers is in accordance with the needs & 203 & 4.1 \\
\hline 2 & Dividing assignments to employees according to their abilities & 410 & 4.1 \\
\hline & TOTAL & 188 & 8.2 \\
\hline B & Labor Productivity Indicator & 188 & 3.8 \\
\hline 1 & Generally satisfied with employee ability & & 3.8 \\
\hline & TOTAL & 182 & 3.6 \\
\hline C & Sales Growth Indicator & 190 & 3.8 \\
\hline 1 & The last three years of the sales growth has increased relatively & 372 & 7.4 \\
\hline 2 & The last three years the net income of restaurant per year relative increased & & \\
\hline & TOTAL & & \\
\hline
\end{tabular}




\section{CONCLUSIONS AND SUGGESTIONS}

Globally from the results of this study can be drawn conclusion Yogyakarta culture has an impact to the management of Padang restaurant in Yogyakarta. In each variable in this study can be described as follows:

\section{Minangkabau Culture variable}

The highest value is the food in halal production and restaurant owners believe with entrepreneurship that help alleviate poverty in Indonesia.

\section{Yogyakarta Cultural variables}

Restaurant owners are always in interacting with employees using bahada yogyakarta and adaptation of taste of cuisine with taste of yogyakarta for example not too salty and spicy.

\section{Business Ability Variables}

Here restaurant owners do not have difficulty in obtaining raw materials to produce cuisine. The ability of business here in terms of ability (Capabilities) refers to the skills (skill) of the company in coordinating resources and put it to use productively.

\section{Business Performance Variables}

Owners of the restaurant easily getting the labor in accordance with needs and abilities that they expected. findings:

This study yields the following important

1. Supporting the opinion of Eka (2013) that saying potential entrepreneurial personality, entrepreneurial knowledge and family environment have a positive and significant impact on entrepreneurial interest.

2. Supports Dalimunthe (2002) research that entrepreneurship has a significant effect on business ability and business success.

3. There is a difference from previous research results from Welsa (2009), especially on non-significant foreigners.

4. The findings of this study are empirically important for the development of entrepreneurial theory and practice in Indonesia.

\section{REFERENCE}

[1] Adam, J. D. 2005. Migrant and Local Entrepreneurial Networks Development. Jurnal Manajemen \& Kewirausahaan 6(2): 93-104.

[2] Alfianto, E. A. 2012. Kewirusahaan Sebuah Kajian Pengabdian Kepada Masyarakat. Journal Heritage 1(2): 33-42).

[3] Andiningtyas R. S. I dan R. L. Nugroho. 2014. Pengaruh Orientasi Kewirausahaan terhadap Kinerja Perusahaan Kecil. Jurnal Manajemen Indonesia 14 (1): 1-19.

[4] Aprilianty, E. 2013. Pengaruh Kepribadian Wirausaha, Pengetahuan Kewirausahaan, dan Lingkungan terhadap Minat Berwirausaha Siswa SMK. Jurnal Pendidikan Vokasi 2(3): 311-324.

[5] Dalimunthe, R. F. 2002. Pengaruh Karakteristik Individu, Kewirausahaan, Gaya Kepemimpinan Terhadap Kemampuan Usaha serta Keberhasilan
Usaha Industri Kecil Tenun dan Bordir di Sumatra utara, Sumatera Barat dan Riau. Dissertation. Surabaya: Airlangga University.

[6] Darwis, R. 2004. Tranformasi Nilai-nilai Tradisi Kekeluargaan Masyarakat Minangkabau dalam Pendidikan Kewiraswastaan. Bandung: Pustaka Aulia Press.

[7] Fauzan. 2011. Pengaruh Religiusitas terhadap Etika Berbisnis (Studi pada RM. Padang di Kota Malang). Jurnal Manajemen dan Kewirausahaan 15(1): 53-64.

[8] Fithri, P. and A. F. Sari. 2012. Analisis Kompetensi Kewirausahaan Industri Kecil Suku Cadang di Kota Padang. Jurnal Optimasi Sistem Industri 11(2): 279292.

[9] Hadiyati, E. 2011. Kreativitas dan Inovasi Berpengaruh Terhadap Kewirausahaan Usaha Kecil. Jurnal Manajemen dan Kewirausahaan 13(1): 8-16.

[10] Koentjaraningrat. 1990. Pengantar Ilmu Antropologi. Jakarta: PT Rineka Cipta.

[11] Kumalaningrum, M. P. 2012. Lingkungan Bisnis, Orientasi Kewirausahaan, Orientasi Pasar dan Kinerja Usaha Mikro, Kecil dan Menengah. JRMB 7(1): 45-59.

[12] Lestari, R. B. dan T. Wijaya. 2012. Pengaruh Pendidikan Kewirausahaan terhadap Minat Berwirausaha Mahasiswa STIE MDP, STMIK MDP, DAN STIE MUSI. Forum Bisnis dan Kewirausahaan Jurnal Ilmiah STIE MDP 1(2): 112-119.

[13] Lukas, S. 2004. Peran Orang Tionghoa dalam Perdagangan dan Hidup Perekonomian dalam Masyarakat (Studi Kepustakaan dan Studi Kasus tentang Interaksi Etnik Tionghoa dan Pribumi di Bidang Perekonomian di Surabaya). Jurnal Manajemen \& Kewirausahaan 5(2): 193-206.

[14] Naim, M. 1979. Merantau, Pola Migrasi Suku Minangkabau. Yogyakarta: Gajah Mada University Press.

[15] Nurseto, T. 2004. Strategi Menumbuhkan Wirausaha Kecil Menengah yang Tangguh. Jurnal Ekonomi \& Pendidikan 1(1): 96-105.

[16] Purhantara, W. 2013. Analisis Kepemilikan Jiwa Kewirausahaan: Evaluasi Outcome Pendidikan Menengah di Jawa. Jurnal Economia 9(2): 175-190.

[17] Purnama, C. 2011. Motivasi dan Kemampuan Usaha dalam Meningkatkan Keberhasilan Usaha Industri Kecil (Studi pada Industri Kecil Sepatu di Jawa Timur). Jurnal Manajemen dan Kewirausahaan 12(2): 177184.

[18] Rante, Y. 2010. Pengaruh Budaya Etnis dan Perilaku Kewirausahaan Terhadap Kinerja Usaha Mikro Kecil Agribisnis di Provinsi Papua. Jurnal Manajemen dan Kewirausahaan 12(2): 133-141.

[19] Reswanda. 2011. Pengaruh Orientasi Kewirausahaan terhadap Pembelajaran Organisasi, Keunggulan Daya Saing Berkelanjutan dan Kinerja Usaha pada UMKM Kerajinan Kulit Berorientasi Ekspor di Sidoarjo. Dissertation. Surabaya: Airlangga University.

[20] Sabri. 2013. Kewirausahaan (Entrepreneurship): Modal Manusia dalam Membangun Perekonomian. Jurnal Ekonomika Universitas Almuslim Bireuen Aceh 4(7): 26-32.

[21] Setiawan, H. 2013. Pengaruh Orientasi Pasar, Budaya Organisasi dan Orientasi Kewirausahaan terhadap Kinerja Usaha (Studi pada Usaha Kecil Pengolahan di Kota Palembang). Jurnal Manajemen dan Bisnis Sriwijaya 11(3): 181-194.

[22] Setyawati, H. A. 2013. Pengaruh Orientasi Kewirausahaan dan Orientasi Pasar terhadap Kinerja Perusahaan Melalui Keunggulan Bersaing dan Persepsi Ketidakpastian Lingkungan Sebagai Prediksi Variabel Moderasi (Survey pada UMKM Perdagangan di 
Kabupaten Kebumen). Journal STIE Putra Bangsa 12(2): 20-31.

[23] Suci, R. P. 2009. Peningkatan Kinerja Melalui Kewirausahaan, Kemampuan Manajemen, Strategi Bisnis (Studi Kasus pada Industri Menengah Bordir di Jawa Timur). Jurnal Manajemen dan Kewirausahaan 11(1): 46-58.

[24] Suharti, L. dan H. Sirine. 2011. Faktor-faktor yang Berpengaruh terhadap Niat Kewirausahaan (Entrepreneurial Intention) (Studi terhadap Mahasiswa Universitas Kristen Satya Wacana Salatiga). Jurnal Manajemen dan Kewirausahaan 13(2): 124-134.

[25] Sulawesi Selatan. Jurnal Ilmiah Bisnis \& Kewirausahaan 4(4): 1-6.

[26] Sultan. 2015. Pengaruh Kompetensi Wirausaha terhadap Strategi, Kinerja Bisnis dan Daya Saing Usaha Kecil. Jurnal Manajemen dan Kewirausahaan 12(2): 185-193.

[27] Welsa, H. 2009. Pengaruh Kewirausahaan terhadap Kemampuan Usaha serta Kinerja Usaha Rumah Makan Padang di Yogyakarta. Jurnal Ekonomi dan Keuangan EKUITAS 13(3): 371-387.

[28] Wijaya, T. 2008. Kajian Model Empiris Perilaku Berwirausaha UKM DIY dan Jawa Tengah. Jurnal Manajemen dan Kewirausahaan 19(2): 93-104. 